\title{
Hjelper selvmordsforebyggende tiltak?
}

Ved N ils Retterstøl

\section{Innledning}

Verdens helseorganisasjon publiserte i 1993 retningslinjer for primærforebygging av psykiske og psykososiale lidel ser. I disse var innlagt føl gende 6 tiltak for selvmordsforebygging:

\section{- bedre behandling av psykiske lidelser}

- bedre kontroll med våpenbesittelse

- avgiftning av husholdningsgass

- avgiftning av bileksos

- kontroll med tilgang til forgiftningsstoffer

- nedtoning av personfokusering vedrørende selvmord i media

Disse tiltakene finner også støtte hos IA SP (International A ssociation for Suicide Prevention) i organisasjonens retningslinjer (IA SP G uidelines for suicide prevention). I dette nummeret av Suicid-ologi vil forskjellige forfattere belyse de nevnte tiltakene. I denne artikkelen vil vi imidlertid se på selvmordsforebyggende tiltak rettet mot mennesker med psykiske lidelser.

Lar det seg bevise at selvmordsforebyggende tiltak virkelig hjel per? H vis vi med bevis mener statistisk signifikante funn, er det tvilsomt. Selvmord forekommer så sjelden at hvis man skulle bevise at et forebyggende tiltak reduserte selvmordshyppigheten med $15 \%$, måtte undersøkelsen omfatte 13 millioner personer.

Skulle man bevise at selvmordshyppigheten falt med $15 \%$ over en 8-årsperiode for den som hadde gjort sel vmordsforsøk, måtte man ta for seg 45000 forsøkere, og skulle man bevise et tilsvarende fall for selvmord i løpet av det første år etter utskrivningen fra en psykiatrisk institusjon, måtte man ta for seg 142000 innlagte pasienter (G unnell \& Frankel 1994). I praksis er dette naturligvis umul ige oppgaver, slik G oldney (1998) drøfter i en utmerket oversikt over den foreliggende litteratur på området. Selv om randomiserte kontrollerte undersøkelser er gullstandarden, finnes det heldigvis alternative metoder for vurdering av effekt. Det er heller ikke bare gjennomførte suicid som er det eneste mål, suicidal atferd kan også reduseres, f.eks selvmordsforsøk. Vi skal i det følgende betrakte nærmere de enkelte forebyggende tiltak som har vært vurdert, og som omtalesav G oldney (1998).

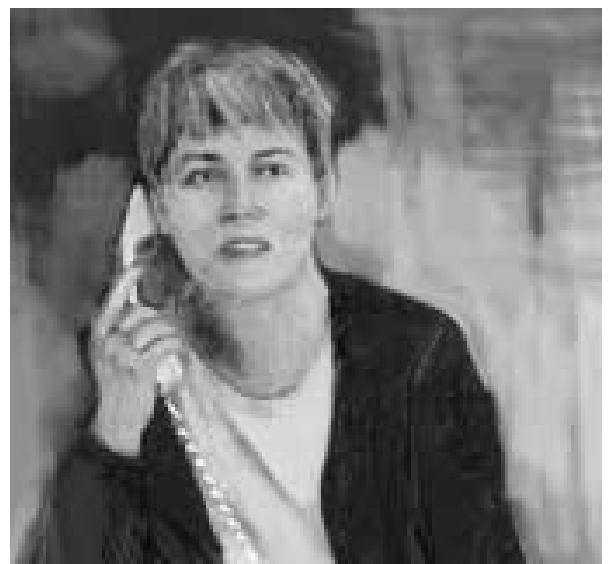

Suicide Prevention Centres. The Samaritans

I løpet av 1950-årene ble Samaritanerbevegelsen etablert i Storbritannia (1953) og Suicide Prevention Centres i USA (1958). I tilknytning til disse har det alltid vært mange frivillige medarbeidere som har gj ennomgått egne kurs og står under faglig veiledning. Fra England har selvmordstallene fra de byer som har samaritanertjeneste gjerne vist en fallende tendens, men de metodologiske problemene ved vurdering av effekten er for store til å trekke sikre konklusjoner (C oppen 1994). I U SA ble selvmordsraten i 25 byer som ikke hadde suicidforebyggende sentre, sammenlignet med 17 byer hvor man hadde dem. O ver en 8-årsperiode (1960-68) ga det ingen signifikant effekt å ha et sel vmordforebyggen de senter i byen. Lester (1974) pekte på at byer med slike sentra gjerne var større enn byer uten, og han gjorde derfor også en sammenlignende undersøkelse mellom like store byer. $\mathrm{H}$ an fant heller ikke da forskjeller. $N$ ye undersøkel ser med mer sofistikerte metoder er imidlertid nå utført av Lester i 1993 og 1994 og av Leenaars og Lester i 1995. I analysene inkluderte de forskjellige risikofaktorer, antall sentre og befolkningsgrunnlag. Konklusjonen var nå at sentrene hadde en preventiv effekt. De antyder at opprettelse av selvmordsforebyggende programmer kanskje gir befolkningen trygghet og håp, og følelse av at samfunnet bryr seg om den enkelte. I et oversiktsarbeid gjennomgår Lester (1997) 14 undersøkelser der man har studert effekten av Suicide Prevention Centres på antall dødsfall ved selvmord, bedømmer dem metodologisk, og finner statistisk støtte for at sentrene har effekt.

\section{Innovative studier}

$\mathrm{N}$ oen etterundersøkelser viser at det nytter å holde kontakt med suicidforsøkerne etter avsluttet behandling. M otto (1976) og M otto og Bostrom (1991) viste at en tilfel dig utval gt gruppe suicidforsøkere som ble kontaktet etter behandlingsslutt først hver måned, senere hver tredje måned og i alt 20 ganger i løpet av fem år, hadde en klart lavere dødelighet i suicid enn en tilsvarende gruppe som ikke ble kontaktet. De Leo og medarbeidere (1995) etablerte en telefonservice for pasienter utskrevet fra en geriatrisk avdeling. Pasientene ble oppringt to ganger i uken, og de kunne selv ringe ved behov. I en fireårsperiode var det bare ett dødsfall i suicid i gruppen mot forventet 7,4 ( av i alt 12135 eldre utskrevne pasienter). Det er neppe bevist at noen psykoterapeutisk metode reduserer suicidaliteten mer enn en annen, men alt tyder på at kontakt, støtte og samtaler over tid har en preventiv virkning.

\section{Medikamentell behandling}

Det ser ut til å være overbevisende dokumentert at riktig bruk av antidepressiv medikasjon reduserer suicidfare. V el kjent er depresjonsprogrammet som ble kjørt over ett år for praktiserende leger på G otIand av Rutz og medarbeidere i 1992, og som resulterte $\mathrm{i}$ økt bruk av antidepressiva og et klart fall i selvmordsraten. M ontgomery og medarbeidere (1995) viste at med behandling med en serotoninreopptakshemmer ble det 5,6 ganger færre selvmord pr. år enn i en placebobehandlet gruppe. Blant dem som fikk behandling, var reduksjonen i antall selvmordsforsøk dobbelt så stor som i placebogruppen.

I sacsson og medarbeidere (1996) beregnet på grunnlag av epidemiologiske data og data over bruk av antidepressiva i Sverige at 100 personer årlig ble beskyttet mot å ta sitt liv av antidepressiva, og at ytterligere 400 personer kunne være reddet årlig ved mer og riktig bruk av antidepressiva. De mener det er et betydelig underforbruk av antidepressiva. D en sterke økningen i bruk av antidepressiva siden 1990-1991 er av avgjørende betydning for den reduksjonen man hadde $\mathrm{i}$ suicidraten i Sverige i de neste tre årene (Isacsson et al. 1997). I et nytt arbeid (2000) mener Isacsson å få bekreftet at 


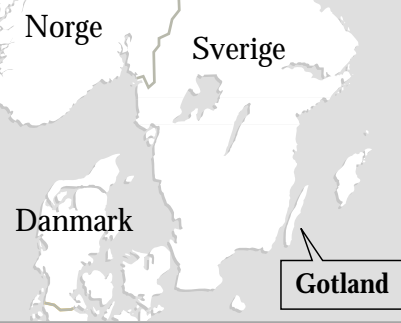

en fortsatt sterk økning i bruk av antidepressiva og en fortsatt betydelig reduksjon i selvmordshyppigheten i Sverige henger sammen. Samme forhold fant han i de andre nordiske land, men også andre psykotrope stoffer kan være selvmordsforebyggende. M eltzer og 0 kayli (1995) viste at clozapin reduserte suicidaliteten sterkt hos schizofrene pasi enter, noe M eltzer (1996) ytterligere kunne bekrefte i et stort materiale av 102000 pasienter behandlet for schizofreni med clozapin. $H$ vorvidt den selvmordsforebyggende effekten virkelig kan tilskrives clozapin eller den bedrete oppfølgingen som behandling med et slikt medikament krever, er imidlertid uavklart.

M eltzer beregnet hyppigheten av selvmord i den behandlede gruppe til å være en fjerdedel av det som var forventet ut fra statistiske vurderinger for vanlige schizofrene. Pasientene i hans gruppe var behandlingsresistente og særlig vanskelige tilfeller, og det var derfor de var satt på clozapin. Erlandsen (2000) har lagt fram et materiale på 103 schizofrene pasienter med alvorlige og langvarige psykoser, behandlet med clozapin mellom 1973 og 1995, det var ingen suicid.

Det er også overbevisende data på at litiumbehandling reduserer suicidhyppigheten. C oppen og medarbeidere (1990) viste at bruk av litium over lengre tid hos pasienter med affektive lidelser reduserte mortaliteten til å bli lik den man fant i den øvrige befolkningen, funn som senere ble gjentatt av A hrens og medarbeidere (1993) i materialer fra Tyskland og Canada, og igjen bekreftet av Coppen i 1994. Både funnene vedrørende clozapin og litium har tidligere vært omtalt i Suicidologi (Retterstøl 1999).

\section{Selvmordsforebyggende programmer}

Det finske selvmordsforebyggende program ble igangsatt i 1989, og er nå evaluert av Beskow og medarbeidere (1999). De fremhever at det kom til et fall i suicidraten på 20 \% i årene 1991-1996 etter en topp i 1990 (innkjøringsfasen). Fra 1986, som er det året man startet forarbeidet, og til 1996 var reduksjonen på $9 \%$. Da var ratene henholdsvis 32,9 og 29,9 . Forfatterne regner med at programmet kan ha vært medvirkende til fallet.
På grunnlag av erfaringene med det finske programmet har U panne (2000) i år beskrevet en modell for analyse av selvmordsforebygging. O gså i N orge har vi grunn til å anta at aktivitetene knyttet til $\mathrm{H}$ andlingsplan mot selvmord har medvirket til den klare reduksjonen (ca $30 \%$ siden 1988) i selvmordsraten som vi har sett. O gså i Sverige har antall selvmord gått betydelig tilbake i samme tidsrom, og man har arbeidet aktivt med forberedel se og igangsetting av en nasjonal handlingsplan som stod ferdig i 1994. Det er sannsynlig at endringer i bruk av antidepressiva fra de sterkt toksiske tricykliske stoffene til SSRI-stoffene har bidratt til tilbakegangen. Ikke minst er behandlingen av depresjoner blitt bedre, bl.a. takket være betydelig kursvirksomhet blant leger og andre fagfolk.

\section{Konklusjon}

Selvmordsforebyggen de arbeid nytter. Vi må arbeide videre med å bedre og utvikle våre forebyggende tiltak.

\section{Litteratur}

A hrens B, M uller- 0 erlinghausen $B$, G raf F: Length of litium treatment needed to eliminate the high mortality of affective disorders. Brit J Psychiatry, 1993; 163 (suppl 21): 27-29

Barraclough BM , Jennings C, M oss JR: Suicide prevention by the Samaritans: A controlled study of effectiveness. Lancet 1977; 2: 868-870

Beskow J, Kerkhof A, Kokkola A, Untela A : Suicide prevention in Finland 1986-1996: External evaluation by an international peer group 1999 (Denne rapporten er tilgjengelig gjennom the M inistry of Social A ffairs and Health, Siltasaarenkatu 18, PO Box 220, SF - $00531 \mathrm{H}$ elsinki, Finland)

Coppen A : D epression as a lethal disease: Prevention strategies. J. Clinical Psychiatry 1994; 55 (suppl 4): 37-45

Coppen A , Standish-Barry H, Bailey J: Long-term litium and mortality. Lancet 1990; 335: 1347

De Leo D, C arollo G, Buono D M : Lower suicide rates associated with a tele-help/tele-check service for the elderly at home. A merican Journal of Psychiatry 1995; 152: 632-634

Erlandsen C: C lozapine for schizophrenia. N ord J. Psychiatry, 2000; 54: 143-148

Goldney RD: Suicide prevention is possible:

A review of recent studies. A rch. Suicide Research 1998; 4: 329-339

G unnell D, Frankel S: Prevention of suicide: aspirations and evidence. Brit. M ed. J 1994; 308: 1227-1233

IA SP G uidelines for Suicide Prevention. http: //www.iasp1960.org/

Isacsson G: Suicide prevention - a medical breakthrough. A cta Psychiatr. Scand. 2000; 102: 113-117
I sacsson $G, H$ olmgren $P$, D ruid $H$, Bergman $U$ : $T$ he utilization of antidepressants - a key issue in the prevention of suicide: an analysis of $\mathbf{5 2 8 1}$ suicides in Sweden during the period 1992-1994. A cta Psychiatr. Scand. 1997; 96: 94-100

Isacsson G, Bergmann U, Rich CL: Epidemiological data suggest antidepressants reduce suicide risk among depressives. J. A ffective Disorders 1996; 41: $1-8$

Leenaars A, Lester D: I mpact of suicide prevention centres on suicide in C anada. C risis 1995; 16: 39

Lester $D:$ T he effectiveness of suicide prevention centres: A review Suicide and Life-T hreatening Behaviour. 1997; 27: 304-310

Lester D: Evaluating the effectiveness of the Samaritans in England and W ales. International Journal of H ealth Services 1994; 5: 73-74

Lester $D: T$ he effectiveness of suicide prevention centres Suicide and Life-T hreatening B ehaviour. 1993; 23: 263-267

Lester D: E ffect of suicide prevention centres on suicide rates in the $\mathrm{U}$ nited States. $\mathrm{H}$ ealth services reports. 1974; 89: 37-39

M eltzer HY: Suicidality and clozapine. J. C linical Psychiatry 1996; 14: 13-14

M eltzer HY, O kayli $\mathrm{G}$ : R eduction of suicidality during clozapine treatment of neuroleptic-resistant schizophrenia: Impact on risk benefit assessment. A m J Psychiatry 1995; 152: 183-190

M ontgomery SA, Dunner DL, Dumbar GC: $R$ eduction of suicidal thoughts with paroxetine in comparison with reference antidepressants and placebo. European N europsychopharmacology 1995; 5: 5-13

M otto J, Bostrom A G : Post-crisis suicide without therapy. Paper presented at the International A ssociation for Suicide Prevention Conference, $\mathrm{H}$ amburg 1991

M otto J: Suicide prevention for high-risk persons who refuse treatment. Suicide and Life-Threatening Behaviour 1976; 6: 223-230

Retterstø| N : Selvmord kan forebygges! - en oversikt over nyere studier. Suicidologi 1999; 4: 22

Rutz W, von Knorring L, W ålinder J: L ong-term effects of an educational program for general practitioners given by the Swedish Committee for prevention and treatment of depression. A cta Psychiatr. Scand. 1992; 85: 83-88

U panne $M$ : A model for analyzing suicide prevention. C risis 2000; 21: 80-90

W orld $\mathrm{H}$ ealth O rganization: $\mathbf{G}$ uidelines for the primary prevention of mental neurological and psychosocial disorders. W H O, G eneva 1993

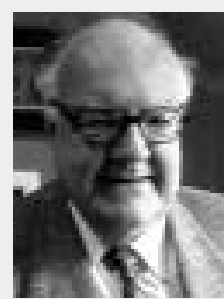
N ils R etterstøl er professor emeritus og har i en årrekke arbeidet med selvmordsproblematikk. H an var president for IA SP - International A ssociation for Suicide Prevention 1989-91 og har utgitt flere lærebøker, bl.a. boken "Selvmord", samt vitenskapelige artikler og avhandlinger. 